\title{
ВПЛИВ РЕПЕРФУЗІЇ НИЖНІХ КІНЦІВОК НА ДИНАМІКУ ЗМІН ПОКАЗНИКІВ ЕНДОГЕННОЇ ІНТОКСИКАЦІЇ ЗА УМОВ ПОЄДНАНОЇ ТРАВМИ ОРГАНІВ ЧЕРЕВНОЇ ПОРОЖНИНИ ТА МАСИВНОЇ КРОВОВТРАТИ
}

Вступ. У статті наведено результати експериментального дослідження, під час якого вивчали вплив реперфузії нижніх кінцівок на розвиток ендогенної інтоксикації при закритій травмі органів черевної порожнини та масивній зовнішній крововтраті. Відомо, що ендогенна інтоксикація є складним багатокомпонентним процесом, зумовленим патологічною біологічною активністю ендогенних продуктів або дисфрункцією систем природної детоксикації. Результати дослідження показали, що реперфузія нижніх кінцівок посилює розвиток ендогенної інтоксикації при поєднаній травмі в експерименті.

Мета дослідження - вивчити вплив реперсузії нижніх кінцівок на зміну окремих показників ендогенної інтоксикації на моделі поєднаної травми органів черевної порожнини на тлі масивної крововтрати.

Методи дослідження. Експеримент проведено на 80-ти нелінійних щурах-самцях масою 190-220 ح. У дослідних групах було змодельовано реперфузію нижніх кінцівок у поєднанні із закритою травмою органів черевної порожнини на тлі масивної крововтрати та проаналізовано вміст маркерів ендогенної інтоксикації (молекул середньої маси фрракцій, що визначались при довжині хвилі 254 і 280 нм) та еритроцитарний індекс інтоксикації. Достовірність відмінностей між контрольною та дослідною групами оцінювали з використанням непараметричного критерію Манна - Уітні.

Результати й обговорення. Накладання кровоспинного джгута на дві нижні кінцівки викликало значне достовірне підвищення показника ендогенного індексу інтоксикації у всіх дослідних групах. Максимальне його збільшення відзначено у групі тварин, в яких накладання джгута поєднувалось із травмою органів черевної порожнини та масивною крововтратою. Це довело потенціюючу дію реперфузійного синдрому на розвиток системних змін при поєднаній травмі. Також доведено, що прояв ендогенної інтоксикації протягом перших 24 год після накладання кровоспинного джгута за своєю силою аналогічний до такого, що виникає внаслідок поєднаної травми органів черевної порожнини на тлі масивної зовнішньої крововтрати.

Висновок. Накладання кровоспинного джгута на дві нижні кінцівки протягом 2 год посилює розвиток ендогенної інтоксикації на моделі поєднаної травми органів черевної порожнини на тлі масивної крововтрати, що підтверджується достовірним зростанням показника ендогенного індексу інтоксикації та молекул середньої маси через 7 діб після реперфузії.

КЛЮЧОВІ СЛОВА: поєднана травма; ендогенна інтоксикація; реперфузія; масивна крововтрата; експеримент; легені.

ВСТУП. Загальновідомо, що в постраждалих у критичному стані розвиваються тканинний оксидативний стрес [1] та інші системні зміни, зокрема ендогенна інтоксикація [1, 2]. В останні роки, зважаючи на вдосконалення методів контролю кровотечі, зросла кількість постраждалих, які вижили на догоспітальному етапі, однак збільшилась кількість летальних випадків на госпітальному етапі. Це зумовлено розвитком у таких пацієнтів системних змін, що в кінцевому результаті призводять до виникнення поліорганної недостатності $[3,4]$. У даному багатокомпо(с) О. В. Федосєєва, 2019 . нентному процесі на особливу увагу заслуговує ендогенна інтоксикація. В його основі лежить дисбаланс системи гомеостазу, в результаті якого в тяжких випадках фрормується синдром поліорганної недостатності [5-7].

В основі розвитку ендогенної інтоксикації лежать гіпоксія, порушення метаболізму та, як наслідок, накопичення недоокиснених продуктів, посилення цитолітичних процесів, вихід в екстрацелюлярний простір протеолітичних ензимів лізосом [8-10].

Зважаючи на характер травми, використання сучасних методів зупинки кровотечі, а саме 
джгутів, та фрормування внаслідок їх застосування процесів реперфузії [11], природно передбачати їх вплив на розвиток системних змін, зокрема ендогенної інтоксикації. Однак наукових досліджень, які б враховували вплив реперфузії на розвиток ендогенної інтоксикації при поєднаній травмі, фрактично немає. Саме тому було заплановано та проведено це дослідження.

Мета дослідження - вивчити вплив реперфрузії нижніх кінцівок на зміну окремих показників ендогенної інтоксикації на моделі поєднаної травми органів черевної порожнини на тлі масивної крововтрати.

МЕТОДИ ДОСЛІДЖЕННЯ. 3 метою реалізації поставленої мети було проведено експериментальне дослідження на 80-ти нелінійних щурах-самцях масою 190-220 г. Піддослідних тварин поділили на контрольну (КГ) і три дослідних групи (ГД) (по 8 щурів у кожній).

Тваринам 1-ї дослідної групи (ГД-1) було змодельовано реперфузію нижніх кінцівок: під тіопентал-натрієвим знеболюванням (40 мг·кг $\left.\Gamma^{-1}\right)$ проксимально на ліві лапки накладали кровоспинний джгут терміном на 120 хв. Для цього застосовували еластичну смужку джгута "SWAT-T" (США) шириною 10 мм, що відповідала ширині джгута при накладанні на стегно дорослій людині. Джгут затягували відповідно до нанесеного на нього індикатора ефективного тиску. Кровоспинний джгут накладали терміном на 2 год 3 метою моделювання ішемічно-реперфузійного синдрому.

Щурам 2-ї дослідної групи (ГД-2) було змодельовано поєднану травму органів черевної порожнини: під тіопентал-натрієвим наркозом (40 мг·кг-1) тварині наносили два дозованих удари в ділянку черевної порожнини за допомогою спеціального пристрою - силу нанесення ударів розраховували таким чином, щоб не виникала внутрішня кровотеча; крововтрати досягали шляхом виконання операційного доступу і пересікання стегнових судин в об'ємі від 20 до $22 \%$ об'єму циркулюючої крові тварини протягом однієї хвилини (гостра крововтрата), після чого кровотечу зупиняли шляхом перев'язування судин.

Тваринам 3-ї дослідної групи (ГД-3) було змодельовано поєднану травму органів черевної порожнини, кровотечу та ішемічно-реперфузійний синдром відповідно до методик, описаних вище.

Тварин дослідних груп виводили з експерименту за умов тіопентал-натрієвого наркозу (60 мг·кг ${ }^{-1}$ ) методом тотального кровопускання із серця через 1, 3 та 7 діб після репердузії. Для дослідження забирали легені щурів.
У крові тварин визначали вміст маркерів ендогенної інтоксикації - молекул середньої маси фрракцій, які визначали при довжині хвилі 254 та 280 нм ( MCM $_{254}$ і MCM $\left._{280}\right)$ та еритроцитарний індекс інтоксикації (EII) [12]. Досліджували зазначені показники в Центральній науковій лабораторії Тернопільського державного медичного університету імені І. Я. Горбачевського.

Достовірність відмінностей між контрольною і дослідними групами оцінювали з використанням непараметричного критерію Манна-Уїтні. Відмінності вважали істинними при вірогідності нульової гіпотези менше $5 \%$ ( $p<0,05)$.

РЕЗУЛЬТАТИ Й ОБГОВОРЕННЯ. ВМІСТ $\mathrm{MCM}_{254}$ підвищувався відносно показників у КГ у всі терміни спостереження (табл. 1). Так, через 1 добу після моделювання травм він достовірно зростав: у ГД-1 - на 50,1 \% ( $<<0,05)$, у ГД-2 - на $150,1 \%(p<0,05)$ та у ГД-3 - на 383,3\% (p<0,05). Через 3 доби рівень MCM $_{254}$ У всіх групах піддослідних тварин був достовірно $(p<0,05)$ більшим від контрольних показників на 100,0, 250,0 та 483,3 \% відповідно. Через 7 діб у ГД-1 він перевищував контроль на 66,7 \% (p<0,05). У ГД-2 зростав та був більшим від контролю на 233,3 \% $(p<0,05)$. У ГД-3 рівень МСM $_{254}$ в ці терміни був достовірно більшим, порівняно з контролем, на $683,3 \%(p<0,05)$.

При аналізі рівня $\mathrm{MCM}_{254}$ в групах піддослідних тварин у контрольних точках дослідження встановлено, що через 1 добу після моделювання травм найбільшим він був у ГД-3. У ГД-1 рівень $\mathrm{MCM}_{254}$ виявився меншим, ніж у ГД-3, на 222,2 \% $\left(p_{1-3}<0,001\right)$, у ГД-2 - на 48,3\% $\left(p_{2-3}<0,01\right)$. Достовірну різницю також зафріксовано між ГД-1 та ГД-2. Так, рівень МСM $_{254}$ у ГД-1 був на 66,7 \% нижчим, ніж у ГД-2 $\left(\mathrm{p}_{1-2}<0,001\right)$. Через 3 доби рівень MCM $_{254}$ зростав у всіх групах та виявився найбільшим у ГД-3. У ГД-3 він був вищим, ніж у ГД-1, на $191,7 \%\left(p_{1-3}<0,001\right)$ та на $66,7 \%$ $\left(p_{2-3}<0,001\right)$ порівняно з ГД-2. У ГД-1 рівень $\mathrm{MCM}_{254}$ достовірно був меншим, ніж у ГД-2, на $135,0 \%\left(p_{1-2}<0,001\right)$. Через 7 діб рівень MCM $_{254}$ зростав відносно попереднього показника у ГД-3, а в ГД-1 та ГД-2 він, навпаки, знижувався. Максимальний рівень зафріксовано у ГД-3, він достовірно перевищував такий у ГД-1 та ГД-2 на $370,0 \%\left(p_{1-3}<0,001\right)$ і $135,0 \%\left(p_{2-3}<0,001\right)$ відповідно.

Вміст $\mathrm{MCM}_{280}$ підвищувався відносно показників у КГ у всі терміни спостереження (табл. 2). Так, через 1 добу після моделювання травм він достовірно зростав: у ГД-1 - на 140,0 \% (p<0,05), у ГД-2-на 240,0\% $(p<0,05)$ та у ГД-3-на 360,0 \% $(p<0,05)$. Через 3 доби рівень MCM $_{280}$ у всіх групах піддослідних тварин був достовірно $(p<0,05)$ 
Таблиця 1 - Вплив реперфузії кінцівки на величину MCM $_{254}$ (ум. од.) у тканині легені (Me (LQ; UQ) - медіана (нижній і верхній квартилі))

\begin{tabular}{|c|c|c|c|c|}
\hline \multirow{2}{*}{ Група дослідження } & \multirow{2}{*}{ Контроль } & \multicolumn{3}{|c|}{ Термін дослідження, доба } \\
\hline & & 1-ша & 3-тя & 7-ма \\
\hline ГД-1 & \multirow[t]{3}{*}{$\begin{array}{c}0,06 \\
(0,04 ; 0,07)(n=10)\end{array}$} & $\begin{array}{c}0,09^{*} \\
(0,08 ; 0,10)(n=8)\end{array}$ & $\begin{array}{c}0,12^{*} \\
(0,10 \cdot 0,15)(n=8)\end{array}$ & $\begin{array}{c}0,10^{*} \\
(0.08: 0,11)(n=8)\end{array}$ \\
\hline ГД-2 & & $\begin{array}{c}0,15^{*} \\
(0,13 ; 0,16)(n=8)\end{array}$ & $\begin{array}{c}0,21^{*} \\
(0,17 ; 0,23)(n=7)\end{array}$ & $\begin{array}{c}0,20^{*} \\
(0,19 ; 0,22)(n=7)\end{array}$ \\
\hline ГД-3 & & $\begin{array}{c}0,29^{*} \\
(0,19 ; 0,30)(n=7)\end{array}$ & $\begin{array}{c}0,35^{\star} \\
(0,32 ; 0,38)(n=6)\end{array}$ & $\begin{array}{c}0,47^{*} \\
(0,42 ; 0,49)(n=6)\end{array}$ \\
\hline \multicolumn{2}{|c|}{$\mathrm{p}_{1-2}$} & $<0,001$ & $<0,05$ & $<0,05$ \\
\hline \multicolumn{2}{|c|}{$p_{1-3}$} & $<0,001$ & $<0,001$ & $<0,001$ \\
\hline \multicolumn{2}{|c|}{$\mathrm{p}_{2-3}$} & $<0,01$ & $<0,001$ & $<0,001$ \\
\hline
\end{tabular}

Примітки. Тут і в таблицях 2, 3:

1. * - відмінності стосовно контрольної групи статистично достовірні $(p<0,05)$.

2. $\mathrm{p}_{1-2}$ - достовірність відмінностей між 1-ю та 2-ю дослідними групами.

3. $\mathrm{p}_{1-3}$ - достовірність відмінностей між 1-ю та 3-ю дослідними групами.

4. $\mathrm{p}_{2-3}$ - достовірність відмінностей між 2-ю та 3-ю дослідними групами.

Таблиця 2 - Вплив реперфузії кінцівки на величину МСМ $_{280}$ (ум. од.) у тканині легені (Me (LQ; UQ) - медіана (нижній і верхній квартилі))

\begin{tabular}{|c|c|c|c|c|}
\hline \multirow{2}{*}{ Група дослідження } & \multirow{2}{*}{ Контроль } & \multicolumn{3}{|c|}{ Термін дослідження, доба } \\
\hline & & 1-ша & 3-тя & 7-мa \\
\hline ГД-1 & \multirow[t]{3}{*}{$\begin{array}{c}0,05 \\
(0,04 ; 0,06)(n=10)\end{array}$} & $\begin{array}{c}0,12^{*} \\
(0,09 ; 0,13)(n=8)\end{array}$ & $\begin{array}{c}0,14^{*} \\
(0,12 ; 0,16)(n=8)\end{array}$ & $\begin{array}{c}0,15^{\star} \\
(0,13 ; 0,16)(n=8)\end{array}$ \\
\hline ГД-2 & & $\begin{array}{c}0,17^{*} \\
(0,14 ; 0,20)(n=8)\end{array}$ & $\begin{array}{c}0,21^{*} \\
(0,19 ; 0,28)(n=7)\end{array}$ & $\begin{array}{c}0,24^{*} \\
(0,22 ; 0,28)(n=7)\end{array}$ \\
\hline ГД-3 & & $\begin{array}{c}0,23^{\star} \\
(0,22 ; 0,27)(n=7)\end{array}$ & $\begin{array}{c}0,37^{*} \\
(0,32 ; 0,40)(n=6)\end{array}$ & $\begin{array}{c}0,46^{*} \\
(0,43 ; 0,50)(n=6)\end{array}$ \\
\hline \multicolumn{2}{|c|}{$\mathrm{p}_{1-2}$} & $<0,05$ & $<0,001$ & $<0,01$ \\
\hline \multicolumn{2}{|c|}{$p_{1-3}$} & $<0,001$ & $<0,001$ & $<0,001$ \\
\hline \multicolumn{2}{|c|}{$p_{2-3}$} & $<0,01$ & $<0,01$ & $<0,001$ \\
\hline
\end{tabular}

більшим від контрольних показників на 180,0, 320,0 та 640,0 \% відповідно. Через 7 діб у гд-1 він перевищував контроль на 200,0% ( $p<0,05)$. У ГД-2 зростав та був більшим від контролю на $380,0 \%$ ( $p<0,05)$. У ГД-3 рівень МСМ $_{280}$ в ці терміни був достовірно більшим, порівняно 3 контролем, на $820,0 \%(p<0,05)$.

При аналізі рівня $\mathrm{MCM}_{280}$ в групах піддослідних тварин у контрольних точках дослідження встановлено, що через 1 добу після моделювання травм найбільшим він був у ГД-3. УГД-1 рівень $\mathrm{MCM}_{280}$ виявився меншим, ніж у ГД-3, на 91,7 \% $\left(p_{1-3}<0,001\right)$, у ГД-2-на 35,3\% $\left(p_{2-3}<0,01\right)$. У ГД-1 він достовірно був нижчим, ніж у ГД-2, на 41,7 \% $\left(p_{1-2}<0,001\right)$. Через 3 доби рівень МCM $_{280}$ зростав у всіх групах піддослідних тварин та виявився найбільшим у ГД-3. У ГД-3 він був вищим, ніж у ГД-1, на $164,3 \%\left(p_{1-3}<0,001\right)$ та на $76,2 \%$ $\left(\mathrm{p}_{2-3}<0,01\right)$ порівняно 3 ГД-2. УГД-1 рівень $\mathrm{MCM}_{280}$ достовірно був меншим, ніж у ГД-2, на 50,0 \% $\left(p_{1-2}<0,001\right)$. Через 7 діб рівень МСM $_{280}$ зростав у всіх групах піддослідних тварин. Максимальний рівень зафіксовано у ГД-3, він достовірно перевищував такий у ГД-1 та ГД-2 на 206,7\% $\left(p_{1-3}<0,001\right)$ і $91,7 \%\left(p_{2-3}<0,001\right)$ відповідно.
Рівень EII підвищувався відносно показників у КГ у всі терміни спостереження (табл. 3). Так, через 1 добу після моделювання травм він достовірно зростав: у ГД-1 - на 188,3 \% (p<0,05), у ГД-2 - на 242,1\% (p<0,05) та у ГД-3-на 355,3 \% $(p<0,05)$. Через 3 доби рівень Ell у всіх групах піддослідних тварин був достовірно $(p<0,05)$ більшим від контрольних показників на 175,9, 286,9 та 415,5 \% відповідно. Через 7 діб у гД-1 він перевищував контроль на 124,3 \% (p<0,05). У ГД-2 зростав та був більшим від контролю на $266,8$ \% ( $<<0,05)$. У ГД-3 рівень EII в ці терміни був достовірно більшим, порівняно з контролем, на $517,7 \%(p<0,05)$.

При аналізі рівня EII в групах піддослідних тварин у контрольних точках дослідження встановлено, що через 1 добу після моделювання травм найбільшим він був у ГД-3. У ГД-1 рівень EII виявився меншим, ніж у ГД-3, на 57,9 \% $\left(p_{1-3}<0,001\right)$, у ГД-2 - на 33,1\% $\left(p_{2-3}<0,001\right)$. Достовірної різниці між ГД-1 та ГД-2 не зафіксовано. Через 3 доби рівень Ell зростав у ГД-2 та ГД-3, в ГД-1 - знижувався. У ГД-3 він був вищим, ніж у ГД-1, на 86,8 \% ( $\left.p_{1-3}<0,001\right)$ та на 33,2 \% $\left(p_{2-3}<0,001\right)$ порівняно 3 ГД-2. У ГД-1 рівень ЕІІ 
Таблиця 3 - Зміна показника еритроцитарного індексу інтоксикації (\%) у сироватці крові піддослідних тварин (Me (LQ; UQ) - медіана (нижній і верхній квартилі))

\begin{tabular}{|c|c|c|c|c|}
\hline \multirow{2}{*}{ Група дослідження } & \multirow{2}{*}{ Контроль } & \multicolumn{3}{|c|}{ "Термін дослідження, доба } \\
\hline & & 1-ша & 3-тя & 7-ма \\
\hline ГД-1 & \multirow[t]{3}{*}{$\begin{array}{c}51,5 \\
(49,9 ; 54,2)(n=10)\end{array}$} & $\begin{array}{c}148,5^{\star} \\
(142,3 ; 158,7)(n=8)\end{array}$ & $\begin{array}{c}142,1^{*} \\
(136,7 ; 150,3)(n=8)\end{array}$ & $\begin{array}{c}115,5^{\star} \\
(105,4 ; 126,4)(n=8)\end{array}$ \\
\hline ГД-2 & & $\begin{array}{c}176,2^{*} \\
(163,9 ; 183,5)(n=8)\end{array}$ & $\begin{array}{c}199,3^{\star} \\
(189,7 ; 210,6)(n=7)\end{array}$ & $\begin{array}{c}188,9^{*} \\
(174,1 ; 202,3)(n=7)\end{array}$ \\
\hline ГД-3 & & $\begin{array}{c}234,5^{\star} \\
(219,8 ; 250,5)(n=7)\end{array}$ & $\begin{array}{c}265,5^{\star} \\
(258,8 ; 281,1)(n=6)\end{array}$ & $\begin{array}{c}318,1^{\star} \\
(302,7 ; 332,3)(n=6)\end{array}$ \\
\hline \multicolumn{2}{|c|}{$p_{1-2}$} & $>0,05$ & $<0,01$ & $<0,001$ \\
\hline \multicolumn{2}{|c|}{$p_{1-3}$} & $<0,001$ & $<0,001$ & $<0,001$ \\
\hline \multicolumn{2}{|c|}{$p_{2-3}$} & $<0,001$ & $<0,001$ & $<0,001$ \\
\hline
\end{tabular}

достовірно був меншим, ніж у ГД-2, на 40,3 \% $\left(p_{1-2}<0,05\right)$. Через 7 діб рівень ЕІІ зростав відносно попереднього показника у ГД-3, а в ГД-1 та ГД-2, навпаки, знижувався. Максимальний рівень зафріксовано у ГД-3, він достовірно перевищував такий у ГД-1 та ГД-2 на $175,4 \%\left(\mathrm{p}_{1-3}<0,001\right) \mathrm{i}$ $68,4 \%\left(\mathrm{p}_{2-3}<0,001\right)$ відповідно.

Таким чином, накладання кровоспинних джгутів на дві нижні кінцівки піддослідних тварин викликало зростання показника Ell протягом усього спостереження. Звертає на себе увагу той фракт, що після 24 год моделювання травм достовірної різниці між групою щурів тільки 3 реперфузією і групою тварин із травмою органів черевної порожнини та кровотечею не було. Найбільш вагомі зміни відзначали в групі піддослідних тварин, в яких реперфрузія кінцівок поєднувалась із травмою органів черевної порожнини та масивною крововтратою. Показник EII в них зростав до кінця спостереження. Це свідчить про те, що реперсрузія нижніх кінцівок значно потенціює розвиток ендогенної інтоксикації при поєднанні з травмою та масивною зовнішньою крововтратою.

ВИСНОВКИ. 1. Реперфузія після накладання кровоспинного джгута протягом 2 год супроводжувалася зростанням показників молекул середньої маси до 7-ї доби спостереження, що достовірно відрізнялися від контрольних: $\mathrm{MCM}_{254}-$ на $66,7 \%(\mathrm{p}<0,05), \mathrm{MCM}_{280}-$ на $200,0 \%$ $(p<0,05)$.

2. У групах піддослідних тварин відзначено значне зростання показника еритроцитарного індексу інтоксикації порівняно з контрольною групою. Так, через 7 діб спостереження в 1-й дослідній групі він достовірно $(p<0,05)$ перевищував контрольний на 124,3\%, у 2-й-на 266,8 \% та в 3-й - на 517,7 \%.

3. Отримані результати дають можливість уточнити деякі аспекти існуючого уявлення про механізми розвитку ендогенної інтоксикації внаслідок накладання кровоспинного джгута. Зокрема, встановлено, що накладання джгута на дві нижні кінцівки на 2 год викликає в піддослідних тварин зміни, які за своєю силою подібні до розвитку ендогенної інтоксикації на моделі щурів із закритою травмою органів черевної порожнини та масивною зовнішньою кровотечею.

Перспективи подальших досліджень подальше вивчення розвитку системних змін на моделі поєднаної травми на тлі гіповолемічного шоку. Також важливим є вивчення питання щодо можливої їх корекції із застосуванням оптимальної схеми інфрузійної терапії та антиоксидантної терапії.
СПИСОК ЛІТЕРАТУРИ

1. Location-dependent effects of trauma on oxidative stress in humans / L. Servia, J. C. E. Serrano, R. PampIona [et al.] // PLoS One. - 2018. - 13 (10). - P. 103-111.

2. Turgay Ş. Response to trauma and metabolic changes: posttraumatic metabolism/Ş. Turgay, U. Ş. Hayal, Z. C. Nuh // Ulus Cerrahi Derg. - 2014. - 30 (3). P. 153-159.

3. The systemic immune response to trauma: an overview of pathophysiology and treatment / J. M. Lord, M. J. Midwinter, Y.-F. Chen [et al.] // Lancet. - 2014. - 384 (9952). - P. 1455-1465.
4. Jenne C. N. Platelets: bridging hemostasis, inflammation, and immunity / C. N. Jenne, R. Urrutia, P. Kubes // Int. J. Lab. Hematol. - 2013. - 35 (3). P. 254-261.

5. Updated concepts on the pathophysiology and the clinical management of trauma hemorrhage and coagulopathy / M. Maegele, Gu Z.-T., Q.-B. Huang, H. Yang // Chin. J Traumatol. - 2017. - 20 (3). - P. 125-132.

6 . Khan S. Damage control resuscitation using blood component therapy in standard doses has a limited effect on coagulopathy during trauma hemorrhage / S. Khan, 
R. Davenport, I. Raza // Intensive Care Med. - 2015. No. 41. - P. 239-247.

7. Volotovska N. V. Changes in the glutathione system's activity of internal organs in the first hours of experimental limb ischemia-reperfusion syndrome, combined with blood loss and mechanical injury N. V. Volotovska, T. Cliff Nhokwara, I. V. Zhulkevych // Здобутки клінічної і експериментальної медицини. 2019. - № 1. - C. 23-27. https://doi.org/10.11603/18112471.2019.v0.i1.10043

8. Козак Д. В. Динаміка синдрому ендогенної інтоксикації в умовах політравми та його корекція карбацетамом / Д. В. Козак // Здобутки клініч. і експерим. медицини. - 2015. - № 2-3. - С. 58-60.

9. The systemic immune response to trauma: an overview of pathophysiology and treatment / J. M. Lord,
M. J. Midwinter, Y.-F. Chen [et al.] // The Lancet. - 2017. 384 (9952). - P. 1455-1465.

10. Systemic inflammation and multiple organ injury in traumatic hemorrhagic shock / H. Liu, X. Xiao, C. Sun [et al.] // Front Biosci (Landmark Ed). - 2015. - No. 20. P. 927-33.

11. Застосування препарату Ентеросгель для профрілактики оксидативного стресу при гострій крововтраті / В. Г. Ніколаєв, І. М. Кліщ, І.В.Жулкевич [та ін.] // Вісн. наук. дослідж. - 2009. - № 1. C. $72-74$.

12. Del Rio D. A review of recent studies on malondialdehyde as toxic molecule and biological marker of oxidative stress / D. Del Rio, A. J. Stewart, N. Pellegrini // Nutr. Metab. Cardiovasc. Dis. - 2005. - 15. P. 316-328.

\section{REFERENCES}

1. Servia, L., Serrano, J.C.E., Pamplona, R., Badia, M., Montserrat, N., Portero-Otin, M., \& Trujillano, J. (2018). Location-dependent effects of trauma on oxidative stress in humans. PLoS One, 13 (10), 103-111.

2. Turgay, Ş., Hayal, U.Ş., \& Nuh, Z.C. (2014). Response to trauma and metabolic changes: posttraumatic metabolism. Ulus Cerrahi Derg., 30 (3), 153-159.

3. Lord, J.M., Midwinter, M.J., Chen, Y.F., Belli, A., Brohi, K., Kovacs, E.J., ..., \& Lilford, R.J. (2014). The systemic immune response to trauma: an overview of pathophysiology and treatment. Lancet, 384 (9952), 1455-1465.

4. Jenne, C.N., Urrutia, R., \& Kubes, P. (2013). Platelets: bridging hemostasis, inflammation, and immunity. Int. J. Lab. Hematol., 35 (3), 254-261.

5. Maegele, M., Gu, Z.-T., Huang, Q.-B., \& Yang, H. (2017). Updated concepts on the pathophysiology and the clinical management of trauma hemorrhage and coagulopathy. Chin. J. Traumatol., 20 (3), 125-132.

6. Khan, S., Davenport, R., \& Raza, I. (2015). Damage control resuscitation using blood component therapy in standard doses has a limited effect on coagulopathy during trauma hemorrhage. Intensive Care Med., 41, 239-247.

7. Volotovska, N.V., Cliff Nhokwara, T., \& Zhulkevych, I.V. (2019). Zminy aktyvnosti hlutationovoi systemy vnutrishnikh orhaniv u pershi hodyny eksperymentalnoho ishemichno-reperfuziinoho syndromu kintsivky, poiednanoho z krovovtratoiu ta mekhanichnoiu travmoiu [Changes in the glutathione systems activity of internal organs in the first hours of experimental limb ischemia- reperfusion syndrome, combined with blood loss and mechanical injury]. Zdobutky klinichnoi i eksperymentalnoi medytsyny - Achievements of Clinical and Experimental Medicine, (1), 23-27 [in Ukrainian]. Retrieved from: https:// doi.org/10.11603/1811-2471.2019.v0.i1.10043

8. Kozak, D.V. (2015). Dynamika syndromu endohennoi intoksykatsii $v$ umovakh politravmy ta yoho korektsiia karbatsetamom [Dynamics of endogenous intoxication syndrome in the conditions of polytrauma and its correction with carbacetam]. Zdobutky klinichnoi ieksperymentalnoi medytsyny-Achievements of Clinical and Experimental Medicine, 2-3, 58-60 [in Ukrainian].

9. Lord, J.M., Midwinter, M.J., Chen, Y.-F., Belli, A., Brohi, K., Kovacs, E.J., ...., \& Lilford, R.J. (2017). The systemic immune response to trauma: an overview of pathophysiology and treatment. The Lancet, 384 (9952), 1455-1465.

10. Liu, H., Xiao, X., Sun, C., Sun, D., Li, Y., \& Yang, M. (2015). Systemic inflammation and multiple organ injury in traumatic hemorrhagic shock. Front Biosci. (Landmark Ed), - 20, 927-933.

11. Nikolaiev, V.H., Klishch, I.M., Zhulkevych, I.V., Oleshchuk, O.M., Nikolaieva, V.V., \& Shevchuk. O.O. (2009). Zastosuvannia preparatu Enteroshel dlia profilaktyky oksydatyvnoho stresu pry hostrii krovovtrati [The use of Enterosgel for the prevention of oxidative stress in acute blood loss]. Visnyk naukovykh doslidzhen - Bulletin of Scientific Research, 1, 72-74 [in Ukrainian].

12. Del Rio, D., Stewart, A.J., \& Pellegrini, N. (2005). A review of recent studies on malondialdehyde as toxic molecule and biological marker of oxidative stress. Nutr. Metab. Cardiovasc. Dis., 15, 316-328. 


\section{ВЛИЯНИЕ РЕПЕРФУЗИИ НИЖНИХ КОНЕЧНОСТЕЙ НА ДИНАМИКУ ИЗМЕНЕНИЙ ПОКАЗАТЕЛЕЙ ЭНДОГЕННОЙ ИНТОКСИКАЦИИ ПРИ СОЧЕТАННОЙ ТРАВМЕ ОРГАНОВ БРЮШНОЙ ПОЛОСТИ И МАССИВНОЙ КРОВОПОТЕРЕ}

\section{Резюме}

Вступление. В статье приведены результаты экспериментального исследования, во время которого изучали влияние реперфузии нижних конечностей на развитие эндогенной интоксикации при закрытой травме органов брюшной полости и массивной наружной кровопотере. Известно, что эндогенная интоксикация является сложным многокомпонентным процессом, обусловленным патологической биологической активностью эндогенных продуктов или дисфункцией систем естественной детоксикации. Результаты исследования показали, что реперфузия нижних конечностей усиливает развитие эндогенной интоксикации при сочетанной травме в эксперименте.

Цель исследования - изучить влияние реперфузии нижних конечностей на изменение отдельных показателей эндогенной интоксикации на модели сочетанной травмы органов брюшной полости на фроне массивной кровопотери.

Методы исследования. Эксперимент проведен на 80-ти нелинейных крысах-самцах массой $190-220$ 2. В исследовательских группах была смоделирована реперфузия нижних конечностей в сочетании с закрытой травмой органов брюшной полости на фроне массивной кровопотери и проанализировано содержание маркеров эндогенной интоксикации (молекул средней массы фрракций, которые определялись при длине волны 254 и 280 нм) и эритроцитарный индекс интоксикации. Достоверность различий между контрольной и исследовательской группами оценивали с использованием непараметрического критерия Манна - Уитни

Результаты и обсуждение. Наложение кровоостанавливающего жгута на две нижние конечности вызвало значительное достоверное увеличение показателя эндогенного индекса интоксикации во всех исследовательских группах. Максимальное его увеличение отмечено в группе животных, у которых наложение жгута сочеталось с травмой органов брюшной полости и массивной кровопотерей. Это доказало потенцирующее действие реперфузионного синдрома на развитие системных изменений при сочетанной травме. Также доказано, что проявление эндогенной интоксикации в течение первых 24 ч после наложения кровоостанавливающего жгута по своей силе аналогично таковому, что возникает вследствие сочетанной травмы органов брюшной полости на фроне массивной наружной кровопотери.

Вывод. Наложение кровоостанавливающего жгута на две нижние конечности в течение 2 ч усиливает развитие эндогенной интоксикации на модели сочетанной травмы органов брюшной полости на фоне массивной кровопотери, что подтверждается достоверным ростом показателя эндогенного индекса интоксикации и молекул средней массы через 7 суток после реперфузии.

КЛЮЧЕВЫЕ СЛОВА: сочетанная травма; эндогенная интоксикация; реперфузия; массивная кровопотеря; эксперимент; легкие.

\section{INFLUENCE OF LOWER LIMBS REPERFUSION ON THE DYNAMICS OF CHANGES IN THE INDICATORS OF ENDOGENIC INTOXICATION IN CONDITIONS OF COMBINED ABDOMINAL INJURY AND MASSIVE BLOOD LOOS}

\section{Summary}

Introduction. The article presents the results of an experimental study that investigated the effect of lower extremity reperfusion on the development of endogenous intoxication with closed trauma of the abdominal organs and massive external blood loss. It is known that endogenous intoxication is a complex multicomponent process, 
caused by pathological biological activity of endogenous products or dysfunction of natural detoxification systems. The results of the study showed that reperfusion of the lower extremities enhances the development of endogenous intoxication with combined trauma in the experiment.

The aim of the study - to learn the effect of lower extremity reperfusion on changes in endogenous intoxication in a model of combined injury of abdominal organs against the background of massive blood loss.

Research Methods. An experiment was conducted on 80 non-linear male rats weighing 190-220 grams. In the experimental groups, reperfusion of the lower extremities in combination with closed trauma of the abdominal organs was simulated against the background of massive blood loss and the content of markers of endogenous intoxication (molecules of the average mass of fractions determined at 254 and $280 \mathrm{~nm}$ ) and erythrocytic intoxication index were analyzed. The likelihood of differences between the control group and the study group was evaluated using the non-parametric Mann-Whitney test.

Results and Discussion. The imposition of hemostatic strap on the two lower extremities caused a significant increase in endogenous intoxication index in all study groups. The maximum increase in the endogenous intoxication index was in the group where the tourniquet was combined with trauma to the abdominal cavity and massive blood loss. This proved the potentiating effect of reperfusion syndrome on the development of systemic changes in combined trauma. It is also proved that the manifestation of endogenous intoxication during the first 24 hours after the imposition of hemostatic straps is similar to that resulting from the combined injury of the abdominal organs against the background of massive external bleeding.

Conclusion. The imposition of hemostatic bundles on the two lower extremities, within two hours, increases the development of endogenous intoxication in the model of combined injury of the abdominal organs against the background of massive blood loss, which is confirmed by a significant increase in the endogenous intoxication index and dementia molecules.

KEY WORDS: combined trauma; endogenous intoxication; reperfusion; massive blood loss; experiment, lungs.

Отримано 08.10.19

Адреса для листування: О. В. Федосєєва, Український науково-практичний чентр екстреної медичної допомоги та медицини катастроф МОЗ України, вул. Братиславська, 3, Київ, 02166, Україна, e-mail: fedoseevaov@ukr.net. 